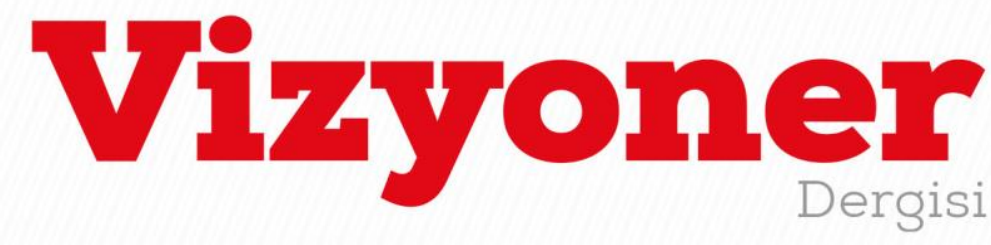

Süleyman Demirel Üniversitesi Vizyoner Dergisi, Yıl: 2021, Cilt: 12, Sayı: 31, 955-971.

Süleyman Demirel University Visionary Journal, Year: 2021, Volume: 12, No: 31, 955-971.

ARAŞTIRMA MAKALESİ / RESEARCH ARTICLE

\title{
INVESTIGATION OF THE RELATIONSHIP BETWEEN INFLUENCERS AND GENERATION Z IN THE CONTEXT OF USES AND GRATIFICATIONS THEORY*
}

\section{INFLUENCERLAR İLE Z KUŞAĞI ARASINDAKİ İLIŞKININ KULLANIMLAR VE DOYUMLAR TEORISII BAĞLAMINDA İNCELENMESİ}

\author{
Deniz YAMAN ${ }^{1}$ \\ Assoc. Prof. Dr. Ömer ÇAKIN ${ }^{2}$
}

\begin{abstract}
The aim of the study is to determine which needs of Generation $\mathrm{Z}$ individuals obtain satisfaction from influencers, who are described as the mechanism of action of social media, and to examine to which extent these satisfaction levels differ in the context of the Uses and Gratifications Theory. The survey method is preferred for the collection of research data; also, Snowball Sampling and Convenience Sampling methods are used in selecting the sample to represent the research population. During the online creation of the survey form, the Google Forms application is used, and the link of the form is made available to the participants via Internet. In the context of research, data is collected from 614 participants, and the responses of 513 individuals who have the necessary prerequisites are evaluated. In the data analyses stage, SPSS 22.0 package program is utilized. The data are subjected to Independent Sample T-Test and ANOVA analyzes in order to determine whether there are any differences between the level of participation of the individuals in the expressions in the scale. According to the results, it is determined that there are statistically significant differences between the participation levels of the individuals.
\end{abstract}

Keywords: Influencer, Generation Z, Uses and Gratifications Theory, Social Media, Internet.

JEL Classification Code: O33.

ÖZ

$\mathrm{Bu}$ araştırmanın amacı, Z Kuşağı bireylerinin sosyal medyanın etki mekanizmaları olarak nitelendirilen influencerlardan hangi gereksinimlerine yönelik tatmin elde ettiklerini belirlemek ve bu tatminlerin ne düzeyde farklılaştığını Kullanımlar ve Doyumlar Teorisi bağlamında incelemektir. Araştırma verilerinin toplanmasında anket yöntemi tercih edilmiş, araştırma evrenini temsil edecek örneklemin seçilmesinde ise Kartopu Örnekleme ve Kolayda yöntemleri kullanılmıştır. Anket formunun çevrim içi ortamda oluşturulması aşamasında Google Formlar uygulaması kullanılmış, forma ait link internet üzerinden katılımcıların erişimine sunulmuştur. Araştırma kapsamında toplam 614 katılımcıdan veri toplanmış, gerekli ön şartları taşıyan 513 katılımcının vermiş olduğu yanıtlar değerlendirmeye alınmıştır. Verilerin analizi aşamasında ise SPSS 22.0 paket programı tercih edilmiş ve kullanılmıştır. Bireylerin ölçekte yer alan ifadelere katılım düzeyleri arasında herhangi bir farklılık olup, olmadığını tespit etmek amacıyla veriler Bağımsız Örneklem T-Testi ve ANOVA analizlerine tabi tutulmuş, elde edilen sonuçlara göre bireylerin katılım düzeyleri arasında istatistiksel olarak anlamlı farklılıklar olduğu belirlenmiştir.

Anahtar Kelimeler: Influencer, Z Kuşağı, Kullanımlar ve Doyumlar Teorisi, Sosyal Medya, İnternet.

JEL Sınıflandırma Kodları: O33.

The paper is prepared from the Master's Thesis titled "Kullanımlar ve Doyumlar Bağlamında Influencer'ların Z Kuşağı Sosyal Medya Kullanıcılarına Etkileri" prepared by Deniz YAMAN under the supervision of Ömer ÇAKIN and defended on 12.06.2020. For this study the approval of ethical committee no 2019-399 dated 29.11.2019 was taken from the Ethical Committee, Ondokuz Mayis University.

1 (D) Süleyman Demirel University, Institute of Social Sciences, Department of Communication Sciences, YÖK 100/2000 PhD Scholarship Student of Süleyman Demirel University, dnzzyaman@gmail.com

2 (D) Ondokuz Mayıs University, Faculty of Communication, Department of Radio, Television and Cinema, omer.cakin@omu.edu.tr

Makale Geliş Tarihi / Received : : 19.02.2021

Makale Kabul Tarihi / Accepted $\quad$ : 21.06.2021 
Süleyman Demirel Üniversitesi Vizyoner Dergisi, Yıl: 2021, Cilt: 12, Sayı: 31, 955-971.

Süleyman Demirel University Visionary Journal, Year: 2021, Volume: 12, No: 31, 955-971.

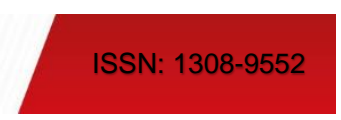

\section{GENIȘLETILMIȘ ÖZET}

\section{Amaç ve Kapsam:}

Bu araştırmanın amacı, Elihu Katz'ın 1959 yılında literatüre kazandırdığı Kullanımlar ve Doyumlar Teorisi çerçevesinde bilgi ve iletişim teknolojileriyle iç içe büyüyen $Z$ kuşağı sosyal medya kullanıcılarının influencerlardan hangi gereksinimlerine yönelik tatmin elde ettiklerini belirlemek ve bu tatminlerin ne düzeyde farklılaştı̆̆ını ortaya koymaktır.

\section{Yöntem:}

Bu çalışmanın evrenini sosyal medya uygulamalarından (Twitter, Facebook, Instagram) en az birini aktif olarak kullanan 1995 yılı ve sonrasında doğan Z kuşağı bireyleri oluşturmaktadır. Örnekleme yöntemi olarak, Kolayda Örnekleme ve Kartopu Örnekleme yöntemleri esas alınmıştır. Araştırmada katılımcılara, iki bölümden oluşan bir sormaca uygulanmıştır. Araştırmada 1973 yılında Katz, Gurevitch ve Haas tarafından yayımlanan çalışma referans alınarak üretilen, bilişsel ihtiyaçlar, duygusal ihtiyaçlar, kişisel bütünleşme ihtiyacl, sosyal bütünleşme ihtiyacl, gerçeklerden kaçış ihtiyacı olmak üzere toplamda beşli kategorileşmeyi temel alan ve 30 soru ifadesinin bulunduğu bir tatmin ölçeği kullanılmıştır. Araştırmada faydalanılan ölçek, Mihalis (Michael) Kuyucu'nun 2016 yılında yapmış olduğu "Kullanımlar ve Doyumlar Perspektifinden Radyo Dinleme Alışkanlıkları ve Doyumları" adlı araştırmasında yer alan ve 30 ifadeden oluşan "Radyo Tatmin Ölçeği"nden uyarlanmıştır. Mihalis (Michael) Kuyucu ile iletişime geçilerek kendisine araştırmanın içeriği hakkındaki detaylar iletilmiş ve araştırmacıdan ölçeğin kullanımına ilişkin gerekli tüm izinler alınmıştır. Araştırma kapsamında katılımcılara uygulanan ve verilerin toplanması hususunda faydalanılan ölçek, Ondokuz Mayıs Üniversitesi Sosyal ve Beşeri Bilimler Araştırma ve Yayın Etiği Kurulu'nun 29.11.2019 tarihli ve 2019-399 numaralı kararı ile onaylanmıştır.

\section{Bulgular:}

Araştırma kapsamında toplanan veriler ilk etapta katılımcıların demografik özelliklerini belirlemek amacıyla çözümlenmiştir. Bir sonraki adımda ise katılımcıların ölçekte yer alan ifadelerden hangisine daha çok katılım gösterdiğini tespit etmek amacıyla betimsel analizlere geçilmiştir. Daha sonrasında, bireylerin ifadelere katılım ve tatmin düzeylerinin cinsiyet, yaş, eğitim durumu ve internet kullanım sıklığına göre farklılık gösterip, göstermediğinin belirlenmesi amacıyla veriler Bağımsız Örneklem TTesti ve Tek Yönlü Varyans (ANOVA) Analizine tabi tutulmuş, farklılıkların kaynağının bulunması için Tukey çözümlemesinden yararlanılmıştır. Araştırma sonunda elde edilen bulgular, Z kuşağı ile influencer ilişkisi hakkında önemli bilgiler vermektedir. Yapılan analiz sonuçlarına göre, influencerların bir ürün ya da hizmete yönelik duygu, düşünce ve deneyimlerinin $Z$ kuşağı bireylerinin satın alma davranışları üzerinde belirleyici bir rol oynadığg saptanmıştır. Z kuşağı ile influencerlar arasındaki ilişkinin bir başka önemli nedeninin ise heyecan unsuru olduğu görülmektedir. Bireyler, adrenalin gereksinimlerini tatmin etmek ve yaşamın tekdüzeliğinden kurtulmak amacı ile heyecan seviyesi yüksek içeriklere sahip kişilerin profillerine yönelmektedirler. Ölçekte yer alan en yüksek katılım düzeyi ortalamasına sahip bir diğer önemli ifade ise influencerların Z kuşağı bireylerinin başarılı olma arzularına ilişkin ifadededir. Bu noktada, bireyler alanında başarılı olan influencerların kendilerine rol model seçerek, kendi yaşamlarında elde ettikleri başarı düzeylerini daha da yukarı taşımayı amaçladıklarına yönelik bir yargıda bulunmak mümkündür. $Z$ kuşağı bireyleri tarafindan kabul gören bir diğer ifade ise influencerların yeni sosyal çevre edinme hususunda kendilerine yardımcı oldukları yönündeki ifadedir. Influencerlar hayran kitlesi milyonlarla ifade edilen kişiler olabilmektedir. Dolayısıyla takipçi kitleleri tarafından bu kişiler adına birçok hayran sayfası oluşturulabilmektedir. Bu girişim sayesinde bireyler, sevdikleri bir influencer için yeni topluluklar oluşturabilmekte, aynı amacı taşıdığı yeni insanlarla etkileşime girerek, onlarla tanışabilme firsatı yakalayabilmektedirler. Son olarak, ölçekte yer alan ve $\mathrm{Z}$ kuşağı üyeleri tarafından en yüksek katılım düzeyi ortalamasına sahip olan ifade ise internetin, toplumsal yaşamın sıkıntılarından arınıp, bireylerin kendi hayal âleminde yaşamalarına yardımcı olduğu yönündeki ifadedir. Çoğu zaman maddi ve manevi kaynaklı sorunlar, bireylerin toplumsal yaşantılarındaki birçok sıkıntının kaynağı olabilmektedir. İnsanlar, bazı durumlarda çaresiz kalabilmekte ve sorunlarla başa çıkmakta kendilerini yetersiz hissedebilmektedirler. Bu noktada internetin sunmuş olduğu sonsuz sanal evren, bireyler için kurtarıcı rolü görmektedir. Bireyler, internet aracılığıla toplumsal hayatın zorluklarından ve sıkıntılarından geçici bir süreliğine de olsa uzaklaşıp, istedikleri sanal kimliğe bürünerek dijitalin sonsuzluğunda düşleri ile baş başa kalabilme imkânına sahip olabilmektedirler.

\section{Sonuç ve Tartışma:}

İletişim teknolojilerinde meydana gelen dijitalleşmenin hızına ayak uydurmak ve adapte olmak her zaman çok kolay olmayabilmektedir. Özellikle X ve Y kuşağı bireyleri için bu süreç biraz zaman alabilmektedir. Fakat Z kuşağı bireylerinin, bu adaptasyon sürecini minimum düzeye indirebildiği ve yeniliklere çok kısa sürede uyum sağlayabilme özelliklerine sahip olduğu yadsınamaz bir gerçektir. Çünkü bu kuşağın bireyleri, gözlerini teknolojinin içine açmakta, doğduğu andan itibaren teknoloji ile iç içe gelişip, büyümektedirler. Dolayısıyla, Z kuşağı bireylerinin diğer kuşak gruplarında yer alan bireylere göre sosyal medyayı farklı gereksinimlerini tatmin etme amacıyla kullandığı gözlemlenmektedir. Hiç kuşkusuz internet ve çevrim içi sosyal platformlar, çağımızın en büyük nimetlerinden sayılmaktadır. İnternet ile görece geç tanışan X ve Y kuşağı üyeleri için çevrim içi sosyal platformlar veya genel tabiriyle sanal uzam pek fazla anlam ifade etmeyebilir ancak bu durum, Z kuşağı bireylerinin vazgeçilmezi arasında yer almaktadır. Dijital çağın çocuklarının ihtiyaçları ve beklentileri, teknoloji ile eş zamanlı olarak gelişmekte ve farklılaşmaktadır. Her geçen saniye takipçi sayısını artıran, etkileşim gücüne güç katan influencerlar ise gelecekte kendilerinden daha da söz ettirecek gibi durmaktadırlar. Dolayısıyla, bu iki grup arasındaki etkileşim ve tatmin ilişkisi, her daim araştırılmayı ve üzerinde düşünülmeyi bekleyen önemli bir çalışma konusu olma değeri taşıyacaktır. 
Süleyman Demirel Üniversitesi Vizyoner Dergisi, Yıl: 2021, Cilt: 12, Sayı: 31, 955-971.

Süleyman Demirel University Visionary Journal, Year: 2021, Volume: 12, No: 31, 955-971.

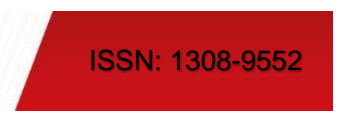

\section{INTRODUCTION}

Developments in the field of information and telecommunications technologies have led to the birth of a new world order. The world has been reformed within its digital framework, free from its traditional ties. The development of Internet technologies and the dissemination of their use by providing ease of access have led to the emergence of the concept of social media over time. Social media has given a new and different dimension to communication between individuals in the digital age in which we live, and has also led to significant changes in the social structure. Social media, where the concepts of place, time and space are abstracted and interaction is instantaneous, has opened the doors to a new universe by offering virtual identities to individuals. The diversity of social media applications over time has led to the emergence of people with a wide audience of followers and the power to interact, referred to as influencers.

The people of Generation Z, who are undoubtedly the children of the digital age, are the most easily adaptable to this rapid movement in Internet technologies. Social media can become an integral part of their lives for Generation $\mathrm{Z}$ individuals, whose profiles are created by their parents in virtual space from the moment they are born, even when they are not yet born, growing intertwined with technology and all kinds of technological devices. Therefore, it is an indisputable fact that Generation $\mathrm{Z}$ individuals may have different expectations and needs compared to Generation $\mathrm{X}$ and $\mathrm{Y}$ individuals. This research aims to determine the level at which Generation $\mathrm{Z}$ social media users are affected by influencers, who have enormous followers and power of interaction, and what needs they use to achieve satisfaction.

\section{LITERATURE}

\subsection{Theoretical Framework of Social Media Concept}

Developments and transformations in communication and internet technologies have led to new practices and needs. With the development and dissemination of the internet, the demand for online platforms has increased, which has led to some new concepts entering our lives. One of these new concepts that are included in our lives is the concept of social media.

Chris Shipley, co-founder of San Francisco-based technology company Guidewire group, was the first to use the concept of social media. This concept covers all online tools that enable information sharing on online platforms, enabling participation and collaboration (Newson, Houghton and Patten, 2008: 49). Jane Bozarth (2010: 11) states that the concept of social media emerged as a result of Web 2.0 technology; besides, the content on social media is produced by the users themselves, not by expert writers or investigative journalists. With this new technology, internet users can produce content on social media networks using all operating systems (Çakın, 2018: 199).

Boyd and Ellison (2008: 211) define social media as web-based systems that allow users to create semi-open or public profiles, select the people they interact with, share links, make the changes they want on these links, and decide who can view the posts. Kim, Jeong and Lee (2010: 216) define social media as websites where individuals create online communities, produce content and share the produced content mutually. According to another definition made by Kaplan and Haenlein (2010: 61), social media refers to internet-based applications that are built on the Web 2.0 infrastructure and allow the user to produce and distribute content. Hazar (2011: 153-154) defines social media as a medium where individuals can fulfill their entertainment, information and socialization needs, personalize their sharing and enable mutual interaction.

\subsection{Action Mechanisms of Social Media: Influencers}

There are many explanations about the concept of influencer, which appears as a relatively new concept in the Turkish literature and is called "influential". Brown and Hayes (2008: 50) describe influencer as individuals who have a large impact and change on consumers' purchasing attitudes. Influencer has an impressive power in the purchasing behavior or decision mechanisms of the individuals for the product or service within the framework of power, potential, knowledge or prestige. According to the definition of Kotler and Armstrong (2011: 139), influencers are opinion leaders who are chosen to represent a brand, product or service. According to another definition, influencers are people with strong personal persuasion, high communication intensity, a wide audience of followers in social media, and their ability to influence individuals is far above average (Zietek, 2016: 9). 
Influencers, who are called opinion leaders of the digital age by Tuten and Solomon (2018: 154), are people that other people see as a source of information. These people have the power to directly or indirectly influence the purchasing attitudes of individuals and have a strong communication network. There are five different characteristics of influencers. Influencers are activists, have a good communication network, can influence people, have an active mind and finally have the power to determine trends. In other words, influencers develop a human network through participation in activities.

The followers of influencers, the new celebrities of the digital universe, which emerged as a result of the development and widespread use of social media, consist of many users with different demographic structure, social status and cultural characteristics. Influencers can share their feelings and thoughts about any product or service with their followers through their active social media accounts, and these shares can affect the viewpoint of the audience towards the product or service. Therefore, Influencers, which have a large audience and interaction power, are an effective method that brands can benefit from in social media marketing strategies (Aslan and Ünlü, 2016: 44). One of the most important reasons underlying this effect is the trust users have in the Influencer they follow.

Influencers are divided into two different categories, micro and macro phenomena, according to the number of followers in their social network accounts. Users with 1000 to 100,000 followers in social network accounts are defined as micro-phenomena, while users with 100,000 to 1,000,000 followers are referred to as macro phenomena (Kangur, 2021). Although micro phenomena have a relatively small audience, these people can have a direct influence on the decision-making mechanism of the audience, as well as having a close communication and interaction with their followers. Macro phenomena, on the other hand, have a wider audience, and the posts they make in their social network accounts can reach a wider audience. However, the relationship and communication link between macro phenomena and their followers may be less and unknown than micro phenomena (Hatton, 2018).

\subsection{Generation Z (1995-...)}

Generation Z, which is formed by individuals whose birth dates are 1995 and beyond, represents a technological new generation born into technology (Karadoğan, 2019: 15). Since the members of this generation open their eyes to the world in the age of technology, they are also named with expressions such as Digital Natives, Internet Generation and Dotcom Children (Csobanka, 2016: 67). Generation Z, which grows intertwined with technology, represents a generation that is more creative, self-confident and has a strong communication compared to previous generations (Erdem, 2018: 219).

Generation $\mathrm{Z}$ is able to provide instant access to information due to efficient and fast use of technology and to do many different jobs simultaneously. For individuals of this generation, distance does not matter. Generation $\mathrm{Z}$ individuals use the power of social media to make new friends and communicate with their existing friends. The term "New Silent Zone" is used for the members of this generation, who maintain their time in virtual space in isolation from the environment (Kırık and Köyüstü, 2018: 1504). As a result of technology and social networks, the members of Generation Z, who utilize the possibility of communicating independently of time and place at the highest level, are becoming more prone to living alone with each passing day. This generation, whose motor skills are the most advanced, are extremely impatient and bored as they are just a click away from everything thanks to internet technologies (Baysal Berkup, 2014: 224). Factors such as increasing terrorist incidents and irregularities in global climate changes have been effective in determining the characteristics of Generation $\mathrm{Z}$ members, who are technology enthusiast and enthusiastic. Experiencing such negative events made Generation Z individuals more cautious and pragmatic, but on the other hand, these negativities experienced inspired the members of this generation, who had to look more realistic towards life, that they could change the world (Sladek and Grabinger, 2013: 2).

Thanks to social media, which enables cross-cultural interaction, Generation $\mathrm{Z}$ individuals have become citizens of the world. Members of this generation can communicate with someone on the other side of the world from their location through social networks. This digital generation, which loves to have fun in virtual space, create and explore new interests, also uses the internet for purposes such as keeping up to date, reporting and sharing developments in the world. 
Süleyman Demirel Üniversitesi Vizyoner Dergisi, Yıl: 2021, Cilt: 12, Sayı: 31, 955-971.

Süleyman Demirel University Visionary Journal, Year: 2021, Volume: 12, No: 31, 955-971.

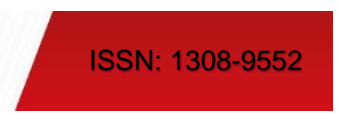

\subsection{Uses and Gratifications Theory}

The unsuccessful results of the researches conducted to determine the effects of mass media on people have led researchers to develop new perspectives and to ask different questions about the problem. This orientation laid the groundwork for the development of the Uses and Gratifications Theory, which looks at the media from a functional perspective (Bal, 2013: 40). Uses and Gratifications Theory came to the fore when Berelson's statement that "the field of communication research seems dead", Elihu Katz's article published in 1959 stated that it was the persuasion studies that actually started to die (Severin and Tankard, 1994: 474). Katz asked, "What are people doing with the media? " by raising the question, it has given a whole new dimension to the work carried out in the field of communication (Sucu 2014: 11).

Uses and Gratifications Theory emphasizes that individuals use the media to fulfill their needs after filtering the content offered to them by the mass media. According to the basic assumption of this approach, the audience is considered as effective as the sender. Rather than the meaning attributed to the message by the sender, the meaning attributed from the audience is prioritized (Fiske, 2003: 193-194). The main idea underlying this theory is that determining the use of media and the satisfaction generated as a result of these uses will allow individuals to identify their psychological and social needs. This theory, developed by Elihu Katz, Jay Blumler and Michael Gurevitch, aims to explain what expectations people's psychological and social needs create for mass media or other media sources (Littlejohn and Foss, 2009: 65). According to Katz, Blumler and Gurevitch (1974: 50) the expectations created by social and psychological based requirements cause differentiate individuals' purpose of using mass media.

Uses and Gratifications Theory claims that the psychological characteristics of the individual and the structure of the society which is a member of constitute the basic elements underlying the emerging needs. These need create some expectations from sources other than mass media and media. Therefore, individuals tend to use mass media or other sources in order to satisfy their needs. As a result of this orientation, needs can reach satisfaction as well as other unexpected outcomes (Çakır and Çakır, 2010: 57). Also, according to this theory According to the Uses and Satisfaction Approach, the communication behavior performed by individuals is purposeful and targetoriented. Using social and psychological factors as a filter, individuals either participate or disagree in media messages according to their needs or expectations. This approach is a psychological communication perspective and focuses on what purposes or functions the media serve for the active audience. The Uses and Gratifications Theory aims to understand the needs of individuals using the media and to determine the results arising from these needs (Chen, 2011: 757).

According to the Uses and Gratifications Theory, which is a theory that aims to determine the purposes and expectations of individuals and to satisfy their needs, the audience plays an active role in the communication process. In addition to the different characteristics of individuals, their social and psychological needs direct them to use different mass media. Elements such as personality traits, social structure, and culture affect the perception of the messages sent through the media (Rubin, 2002: 538). The Uses and Gratifications Theory consists of four basic concepts: active audience, gratifications sought, gratifications obtained and satisfaction (Birsen, 2005: 31).

\subsubsection{Active Audience}

One of the most important concept of the Uses and Gratifications Theory is active audience. This concept brings some criticism to approaches that perceive individuals as passive in the mass media. According to this concept, individuals/viewers prefer mass media in line with their needs. Therefore, individuals play an active role, rather than passive, in this communication process. Individuals do not accept every message coming from the mass media as they are, while making their choices, they prefer the most suitable one among them by keeping their needs in the forefront. The concept of active audience states that individuals use mass media consciously and in a way that serves their own purposes.

The concept of active audience expresses the voluntary preferences of individuals and the selectivity of their relationship with the mass media. According to this concept, the responses of viewers who are exposed to media messages bear traces of individuals' social relationships, interests and past experiences (Turow, 2009: 160). Uses and Gratifications Theory accepts the audience as active and talented in terms of media preferences and uses. This approach also rejects the assumption that the traces put forward during the impact research period were captured by the media by influencing the audience. Contrary to this view, it argues that the media is a tool set that individuals use freely to repair a number of different needs (Laughey, 2010: 59). 
Demographic factors such as education level and age of individuals and structural characteristics of the preferred media channel have an important effect in determining the activity level. Each individual has different characteristics and needs from each other. Therefore, each individual reproduces the meanings of the messages transmitted by the mass media in the perspective of these differences. In addition, there is a prerequisite for the individual to have at least basic knowledge about the medium in order to make the choice of the mass media that will satisfy his/her needs (Bayram, 2007: 42). According to the concept of active audience, the individual/audience is aware of their needs. Individuals evaluate the content produced by various media channels, filter them according to their needs and choose the tool that they believe will reach satisfaction. However, if individuals think that any of the communication tools will be inadequate or unable to meet their current needs, they start to look for alternative solutions to satisfy this need (Kim, 2002: 17).

Jay Blumler (1979: 13), states that the audience is active in four different situations in which utility, intention, selectivity and non-influence are observed. According to Blumler, benefit is the communication purposes of individuals; intention is the planned structure of communication; The selectivity, interest and anticipation-oriented communication tool preference, and finally, being closed to influence, refers to the individuals' act of resisting against all kinds of content transmitted through mass media. There are two important elements at the basis of the concept of active tracks audience. First of all, individuals have to take responsibility for the consequences that may or may occur in the communication process, since they make their choices for mass communication channels in line with their own wishes and expectations. Therefore, media professionals and content producers cannot be held liable or suspect in any way whatsoever. The second important point is that if the choice of the individual/audience for communication channels is insufficient or not successful in fulfilling their needs, this leads individuals/viewers to seek different resources to satisfy their needs (Erdoğan and Alemdar, 1990: 114).

\subsubsection{Gratifications Sought}

The needs of individuals are the basic elements used in explaining the reasons for the use of mass media within the framework of Uses and Gratifications Theory. Individuals with certain personal and social needs desire to satisfy these needs through mass media and thus get rid of their tension. Alternative ways such as traveling, participating in sports activities and acquiring hobbies are among the solutions that individuals can apply to meet their needs. However, when personal and environmental opportunities are not sufficient to meet the needs, individuals turn to mass media and aim to satisfy their needs in this way by making some choices among the contents (Uzun, 2013: 89).

Individuals use mass media to satisfy some of their different and complex needs. This situation is an indication that individuals seek certain satisfaction. Needs or motives cause the satisfaction sought to emerge and this situation triggers the behavior of using mass media (Erdoğan and Alemdar, 1990: 110). It is stated that media contents, which are indispensable for activities such as getting away from the stress of daily life, entertainment and leisure time, serve as a psychological satisfaction tool within the scope of Uses and Gratifications Theory. Media contents, which are structurally suitable for both individual and group consumption, can provide satisfaction in both situations (Çakır, 2005: 42).

\subsubsection{Needs and Motivations}

According to the Uses and Gratifications Theory, which places the audience at the center of the communication process, the activities of individuals constitute the beginning of information. Needs shape the relationship structures of individuals with their social environment. Individuals act with the motive to fulfill their needs (Ayhan and Çavuş, 2014: 36). Therefore, in line with this purpose, individuals prefer the communication channel that they believe which is the best choice to satisfy their needs among the mass media and the content offered through these tools. Correct choices not only satisfy the needs of individuals, but also eliminate possible stress situations. When the choices made within the existing possibilities are insufficient to satisfy the needs, individuals start to seek alternative solutions to achieve satisfaction (Erdoğan and Alemdar, 1990: 108).

Needs, which have a biological and psychological structure, form the basis of individuals' social behaviors. Motivations are the things that direct the cognitive and behavioral human actions carried out in order to satisfy the needs. Motivations are cognitive orientations that aim to satisfy needs. The social structure inhabited plays an active role in determining the needs of individuals (Lull, 2001: 137-142). 


\subsubsection{Gratifications Obtained}

While the gratifications sought is expressed as the satisfaction that the audience wishes to achieve before the audience decides to use a mass media tool; the gratifications obtained is explained as the satisfaction achieved by the audience as a result of the experience of a mass media tool. If the gratifications obtained is sufficient to satisfy the expectations or if it provides more than the expected, the use of the vehicle can turn into a consumption demand. When faced with an opposite situation, the use of the vehicle may gradually decrease and individuals may tend to experience different tools (Köseoğlu, 2012: 65). The concepts of gratifications sought and gratifications obtained that are mentioned about the existence of a reciprocal and cyclical relationship between them contain some differences. Individuals with the desired satisfaction make use of media after determining their needs. The gratifications obtained refers to the satisfaction individuals provide after using media. As a result of the high gratifications obtained, individuals' expectations for media use would rise (Birsen, 2005: 37-38).

\section{METHOD}

This research was created on the basis of the Uses and Gratifications Theory and was conducted to determine the differences of satisfaction levels of Generation $\mathrm{Z}$ social media users from influencers. In this purpose, a questionnaire form consisting of two parts was prepared and applied to the participants. Within the scope of this research, Convenience Sampling and Snowball Sampling methods, which are non-probability sampling methods, were used.

The questionnaire form applied to the participants within the scope of the study was adapted from the "Radio Satisfaction Scale", which was included in the "Radio Listening Habits and Gratifications from the Perspective of Usages and Gratifications" research conducted by Mihalis (Michael) Kuyucu in 2016 and consists of 30 statements in total. In the first part of the questionnaire form, a total of 6 multiple-choice questions were asked to determine the personal (demographic) characteristics of the participants, their daily internet usage times and the social media applications they actively use. In the second part of the form, a satisfaction scale was used based on the article by Elihu Katz, Michael Gurevitch and Hadassah Haas in 1973 to determine the level at which Generation Z social media users were affected by influencers and to gather their opinions in the perspective of Uses and Gratifications Theory. This scale consists of 30 question expressions and is based on a total of five categorizations: cognitive needs, affective needs, integrative needs, integrative function and needs related to escape. The scale which is used in this study to gather data was approved Ondokuz Mayıs University, Social Sciences and Humanities Research and Publication Ethics Committee on 29.11.2019, with the decision number 2019-399.

\section{ANALYSIS AND INTERPRETATION OF DATA}

In the first place, frequency analysis was applied to the data obtained within the scope of the research and it was determined the demographic characteristics of the participants, the frequency of daily internet use and what the social media applications they actively use. In the continuation of the process, reliability and structural validity analyzes were applied to the scale used in the research. After the reliability and structural validity analysis, factor analysis was applied and it was observed that the data were collected under 5 factors. After completing the factor analysis, descriptive analyses were carried out and the mean and standard deviation values of the participants ' responses were included. Following the descriptive analysis, statistical analysis of the data was completed and it was examined whether the effects of influencers on Generation $\mathrm{Z}$ individuals differed depending on the age, gender, frequency of internet use and educational status of the participants. In this context, Independent Sample T Test for gender in order to determine the differences; ANOVA analyzes were used for age, education level and internet usage frequency. IBM SPSS Statistics 22.0 for Windows package program was used to analyze the data obtained from the participants.

\subsection{Reliability Analysis}

In the reliability analysis using the Cronbach's Alpha coefficient, the relevant coefficient has a value between 0 and 1 . The reliability of the survey increases as the coefficient value approaches 1 , and it is accepted that the survey is reliable in cases where the value is above 0.70 (Özdamar 2002: 513). 
Süleyman Demirel Üniversitesi Vizyoner Dergisi, Yıl: 2021, Cilt: 12, Sayı: 31, 955-971.

Süleyman Demirel University Visionary Journal, Year: 2021, Volume: 12, No: 31, 955-971.

Table 1. Results of Reliability Analysis

\begin{tabular}{llll}
\hline & Cronbach's Alpha & Cronbach's Alpha Based on Std. Items & N of Items \\
\hline Influencer Satisfaction Scale & 0,947 & 0,947 & 30 \\
\hline
\end{tabular}

As a result of the Reliability Analysis that the scale used in the study was subjected to in order to determine the representation power of the research and to measure its reliability, it was determined that the Cronbach's Alpha reliability coefficients of the scale and its sub-dimensions were well above 0.70 .

\subsection{Structural Validity and Factor Analysis}

KMO and Bartlett analysis were used to control the structural validity of the scale used in this study. As seen in Table 2, the KMO value of the scale used in the study was found to be 0.942 ; It was observed that the $\mathrm{p}$ value for the Bartlett analysis was $p=0,000<\alpha=0,05$. The fact that the KMO value is greater than 0,60 and the $p$ value obtained as a result of the Bartlett test has a meaningful quality less than 0,05 indicates that the scale has construct validity (Büyüköztürk 2006: 179). As a result of the value obtained as a result of KMO analysis being greater than 0.60 , the suitability of the data for factor analysis has been approved.

Table 2. Result of Structural Validity Analysis

\begin{tabular}{lll}
\hline \multicolumn{2}{l}{ Kaiser-Meyer-Olkin Measure of Sampling Adequacy. } & 0,942 \\
\hline \multirow{3}{*}{ Bartlett's Test of Sphericity } & Approx. Chi-Square & 10594,177 \\
& df & 435 \\
& Sig. & 0,000 \\
\hline
\end{tabular}

Table 3. Total Variance Explained

\begin{tabular}{cccccccccc}
\hline \multirow{2}{*}{ Component } & \multicolumn{3}{c}{ Initial Eigenvalues } & \multicolumn{3}{c}{$\begin{array}{c}\text { Extraction Sums of Squared } \\
\text { Loadings }\end{array}$} & \multicolumn{3}{c}{$\begin{array}{c}\text { Rotation Sums of Squared } \\
\text { Loadings }\end{array}$} \\
\cline { 2 - 10 } & Total & $\begin{array}{c}\text { Variance } \\
\text { \% }\end{array}$ & $\begin{array}{c}\text { Cumulative } \\
\text { \% }\end{array}$ & Total & $\begin{array}{c}\text { Variance } \\
\text { \% }\end{array}$ & $\begin{array}{c}\text { Cumulative } \\
\text { \% }\end{array}$ & Total & $\begin{array}{c}\text { Variance } \\
\text { \% }\end{array}$ & $\begin{array}{c}\text { Cumulative } \\
\text { \% }\end{array}$ \\
\hline 1 & 12,224 & 40,748 & 40,748 & 12,224 & 40,748 & 40,748 & 6,691 & 22,305 & 22,305 \\
2 & 3,428 & 11,426 & 52,174 & 3,428 & 11,426 & 52,174 & 6,137 & 20,456 & 42,761 \\
3 & 1,579 & 5,263 & 57,437 & 1,579 & 5,263 & 57,437 & 3,642 & 12,140 & 54,901 \\
4 & 1,409 & 4,698 & 62,135 & 1,409 & 4,698 & 62,135 & 2,015 & 6,716 & 61,618 \\
5 & 0,955 & 3,182 & 65,317 & 0,955 & 3,182 & 65,317 & 1,110 & 3,699 & 65,317 \\
\hline
\end{tabular}

After confirming the suitability of the scale used in the study with a total of 30 expressions for factor analysis, exploratory factor analysis was started, and as a result of the factor analysis using the Varimax vertical rotation method, it was observed that the expressions in the scale could be collected under a total of five factors. As a result of the analysis, it was determined that the percentage of explanation of the variance of five factors was $65.317 \%$. If the total variance explained has a value of more than $40 \%$, it can be said that the scale has a strong structural validity (Kuyucu, 2016: 311).

\subsection{Demographic Characteristics of Individuals}

Tables including gender, age, and education information of the participants who contributed to the study are given below.

Table 4. Distribution of Individuals by Gender

\begin{tabular}{ccc}
\hline Gender & Frequency $(\mathbf{n})$ & Percent $(\boldsymbol{\%})$ \\
\hline Female & 234 & 45,6 \\
Male & 279 & 54,4 \\
Total & 513 & 100 \\
\hline
\end{tabular}


Süleyman Demirel Üniversitesi Vizyoner Dergisi, Yıl: 2021, Cilt: 12, Sayı: 31, 955-971.

Süleyman Demirel University Visionary Journal, Year: 2021, Volume: 12, No: 31, 955-971.

According to the above information, it is observed that the vast majority of the individuals involved in the study were male $(\% 54,4)$.

Table 5. Distribution of Individuals by Age

\begin{tabular}{ccc}
\hline Age & Frequency $(\mathbf{n})$ & Percent $(\boldsymbol{\%})$ \\
\hline 18 & 92 & 17,9 \\
19 & 101 & 19,7 \\
20 & 98 & 19,1 \\
21 & 70 & 13,7 \\
22 & 47 & 9,2 \\
23 & 51 & 9,9 \\
24 & 37 & 7,2 \\
25 & 17 & 3,3 \\
Total & 513 & 100 \\
\hline
\end{tabular}

The information on the distribution of the individuals participating in the study by age groups is given in Table 5 . Within the framework of this information, the age ranking of the individuals participating in the research is as follows, from highest to lowest; age $19(\% 19,7)$, age $20(\% 19,1)$, age $18(\% 17,9)$, age $21(\% 13,7)$, age $23(\% 9,9)$, age $22(\% 9,2)$, age $24(\% 7,2)$ and age $25(\% 3,3)$.

Table 6. Distribution of Individuals by Educational Status

\begin{tabular}{ccc}
\hline Educational Status & Frequency $(\mathbf{n})$ & Percent $(\boldsymbol{\%})$ \\
\hline Secondary Education & 159 & 31 \\
Bachelor's Degree & 289 & 56,3 \\
Postgraduate Degree & 65 & 12,7 \\
Total & 513 & 100 \\
\hline
\end{tabular}

Information on the distribution of the individuals participating in the study according to their educational status is given in Table 6. As a result of the data collected from the participants, it was determined that none of them had a primary education level, and as a result, the item on the primary education level was not given above. When data on the level of education of the participants are examined, it is seen that $31 \%$ of the participants had secondary education, $56.3 \%$ had a bachelor's degree and $12.7 \%$ had a postgraduate level education.

\subsection{Evaluations of Individuals' Preferences and Usage Times for Social Media Applications}

In addition to the questions asked to determine their demographic characteristics, Generation $\mathrm{Z}$ individuals participating in the study were asked to answer questions about the frequency of using online social media applications and which application they prefer to use more. Tables created in line with the data collected from the participants are listed below.

Table 7. Daily Internet Usage Times of Individuals

\begin{tabular}{ccc}
\hline Time & Frequency $(\mathbf{n})$ & Percent $(\boldsymbol{\%})$ \\
\hline Between 1-3 hours & 43 & 8,4 \\
Between 3-5 hours & 113 & 22 \\
Between 5-7 hours & 174 & 33,9 \\
Between 10+ hours & 183 & 35,7 \\
Total & 513 & 100 \\
\hline
\end{tabular}

Information on the daily internet usage times of the participants is shown in Table 7. In line with the values in the table, $8.4 \%$ of the 513 participants participating in the study use the internet for 1-3 hours per day, $22 \%$ for 3-5 hours, $33.9 \%$ for $5-7$ hours, $\% 35,7$ of them use it for 10 hours or more. Considering the data in the table, it can be 
Süleyman Demirel Üniversitesi Vizyoner Dergisi, Yıl: 2021, Cilt: 12, Sayı: 31, 955-971.

Süleyman Demirel University Visionary Journal, Year: 2021, Volume: 12, No: 31, 955-971.

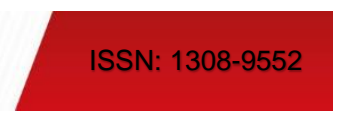

interpreted that the internet has a very important place in the lives of Generation Z individuals, who are the children of the digital age, and that these individuals spend almost half of the 24-hour time period corresponding to a day in virtual space.

Table 8. Preferences of Individuals for Social Media Applications

\begin{tabular}{ccc}
\hline Social Media Applications & Frequency $(\mathbf{n})$ & Percent $(\boldsymbol{\%})$ \\
\hline Instagram & 498 & 34 \\
YouTube & 376 & 26 \\
Twitter & 271 & 18 \\
Facebook & 193 & 13 \\
Others & 139 & 9 \\
Total & 1477 & 100 \\
\hline
\end{tabular}

Information on the preferences of the individuals participating in the study for online social media applications is shown in Table 8. In the study, the participants were given the opportunity to make multiple choices regarding social media applications. For this reason, the sum of the answers obtained is higher than the total number of participants in the study. According to statistics above, the most commonly preferred and used social media platforms for Generation Z individuals, who live in Turkey, are Instagram, YouTube, Twitter, Facebook and other applications.

\subsection{Descriptive Statistics}

A scale including 30 expressions under the categories of cognitive needs, affective needs, integrative needs, integrative function and needs related to escape was applied to the individuals of Generation $\mathrm{Z}$ who participated in the study. Participants answered the expressions they found the most appropriate by marking the option on the 5-likert scale (1-Strongly Disagree, 2-Disagree, 3-Neutral, 4-Agree, 5-Strongly Agree). Information on the mean and standard deviation values of the answers collected from 513 people who were evaluated within the scope of the study are detailed in Table 9.

Table 9. Expressions in which Individuals Participated at the Highest Level

\begin{tabular}{|c|c|c|c|}
\hline & Influencer Satisfaction Scale & Mean & Std. Deviation \\
\hline Cognitive Needs $(\mathrm{CN})$ & Influencers help me with what and where to buy when shopping. & 4,58 & 0,799 \\
\hline Affective Needs (AN) & $\begin{array}{l}\text { Influencers have an effect that makes me excited by exploring } \\
\text { some exciting topics. }\end{array}$ & 4,24 & 0,703 \\
\hline Integrative Needs (IN) & Influencers increase my desire to be successful. & 4,04 & 0,784 \\
\hline Integrative Function (IF) & Influencers help me to get a new social environment. & 3,55 & 0,967 \\
\hline $\begin{array}{l}\text { Needs Related to } \\
\text { Escape (NRE) }\end{array}$ & $\begin{array}{l}\text { The Internet helps me get rid of the troubles of social life and } \\
\text { live in my own dream world. }\end{array}$ & 4,60 & 0,900 \\
\hline
\end{tabular}

By examining the total responses and participation levels of Generation $\mathrm{Z}$ individuals participating in the study to the expressions contained in the scale, the following conclusions were obtained; it was observed that individuals most positively participated in the expression "influencers help me with what and where to buy when shopping" from the expressions under the dimension of cognitive needs contained in the scale (mean 4,58; std. deviation 0,799). Under the affective needs dimension, it was determined that the individuals most positively agree with the expression "influencers have an effect that makes me excited by exploring some exciting topics" (mean 4,24; std. deviation 0,703). Under the integrative needs dimension in the scale, individuals most positively agreed with the expression "influencers increase my desire to be successful" (mean 4,04; std. deviation 0,784). Under the integrative function dimension in the scale, it was observed that the individuals most positively agreed with the expression "influencers help me to get a new social environment" (mean 3,55; std. deviation 0,967). In the last dimension of the scale, which is needs related to escape, it was determined that the individuals most positively agreed with the expression "the internet helps me get rid of the troubles of social life and live in my own dream world" (mean 4,60; std. deviation 0,900). 


\subsection{Statistical Analysis}

It was examined whether the obtain satisfaction level of Generation $\mathrm{Z}$ individuals differed depending on the age, gender, frequency of internet use and educational status of participants. In this context, Independent Sample T Test for gender in order to determine the differences; ANOVA analyzes were used for age, education level and internet usage frequency. IBM SPSS Statistics 22.0 for Windows package program was used to analyze the data obtained from the participants.

\subsubsection{Variability Analysis According to Gender Characteristics of the Individuals}

In order to determine whether the gender characteristics of the individuals have any effect on the differentiation of their level of participation in the expressions in the research scale, the data were subjected to the Independent Sample T test. Detailed information on the analysis results is given in Table 10.

Table 10. Independent Sample T-Test According to the Gender of Individuals

\begin{tabular}{|c|c|c|c|c|c|c|}
\hline & Gender & $\mathbf{N}$ & Mean & SD & $\mathbf{t}$ & $\mathbf{p}$ \\
\hline \multirow{2}{*}{ Cognitive Needs } & Female & 234 & 3,6439 & 0,69928 & \multirow{2}{*}{4,979} & \multirow{2}{*}{0,041} \\
\hline & Male & 279 & 3,9504 & 0,69054 & & \\
\hline \multirow{2}{*}{ Affective Needs } & Female & 234 & 3,2536 & 0,58580 & \multirow{2}{*}{4,318} & \multirow{2}{*}{0,035} \\
\hline & Male & 279 & 3,4618 & 0,48943 & & \\
\hline \multirow{2}{*}{ Integrative Needs } & Female & 234 & 3,0100 & 0,53748 & \multirow{2}{*}{4,744} & \multirow{2}{*}{0,019} \\
\hline & Male & 279 & 3,2318 & 0,51887 & & \\
\hline \multirow{2}{*}{ Integrative Function } & Female & 234 & 2,8205 & 0,61964 & \multirow{2}{*}{7,442} & \multirow{2}{*}{0,014} \\
\hline & Male & 279 & 3,2127 & 0,57246 & & \\
\hline \multirow{2}{*}{ Needs Related to Escape } & Female & 234 & 3,7009 & 0,62782 & \multirow{2}{*}{2,458} & \multirow{2}{*}{0,027} \\
\hline & Male & 279 & 3,8297 & 0,54530 & & \\
\hline
\end{tabular}

According to Independent Sample T-Test results; it was determined that the participation levels of the subexpressions of the cognitive needs, affective needs, integrative needs, integrative function and needs related to escape categories in the scale significantly differed according to the gender characteristics of the individuals $(\mathrm{p}=$ $0,041 ; \mathrm{p}=0,035 ; 0,019, \mathrm{p}=0,014$ and $\mathrm{p}=0,027<\alpha=0,05)$. According to the results obtained, it was determined that male individuals approached the expressions in the sub-dimensions of all categories more positively than female individuals.

\subsubsection{ANOVA Analysis for Ages of Individuals}

Details on the results of ANOVA analysis applied to determine the relationship between the ages of the participants and their level of participation in the expressions in the scale are given in Table 11.

Table 11. Results of ANOVA Analysis on the Relationship Between Age and Levels of Participation in Expressions in the Scale

\begin{tabular}{ccccccc}
\hline & Age & N & Mean & SD & F & p \\
\hline \multirow{6}{*}{ CN } & $18-19$ & 193 & 3,9283 & 0,67757 & & \\
& $20-22$ & 215 & 3,7070 & 0,78219 & & 0,007 \\
& $23-25$ & 105 & 3,8063 & 0,57509 & 5,015 & 0,036 \\
& Total & 513 & 3,8106 & 0,71049 & & \\
& $18-19$ & 193 & 3,4223 & 0,53441 & & \\
& $20-22$ & 215 & 3,2938 & 0,59363 & & \\
& $23-25$ & 105 & 3,4143 & 0,43677 & & \\
\end{tabular}


Süleyman Demirel Üniversitesi Vizyoner Dergisi, Yıl: 2021, Cilt: 12, Sayı: 31, 955-971.

Süleyman Demirel University Visionary Journal, Year: 2021, Volume: 12, No: 31, 955-971.

\begin{tabular}{ccccccc}
\hline & Age & N & Mean & SD & F & p \\
\hline \multirow{3}{*}{ IN } & $18-19$ & 193 & 3,1477 & 0,47194 & & 0,481 \\
& $20-22$ & 215 & 3,0977 & 0,59943 & 0,734 & \\
& $23-25$ & 105 & 3,1667 & 0,52195 & & 0,491 \\
\hline \multirow{3}{*}{ IF } & Total & 513 & 3,1306 & 0,53840 & & \\
& $18-19$ & 193 & 3,0570 & 0,57073 & & 0,713 \\
& $20-22$ & 215 & 2,9953 & 0,68905 & & \\
& $23-25$ & 105 & 3,0698 & 0,58369 & & \\
& Total & 513 & 3,0338 & 0,62521 & & \\
& $18-19$ & 193 & 3,7902 & 0,55421 & & \\
& $20-22$ & 215 & 3,6953 & 0,62948 & & \\
\end{tabular}

According to the results of ANOVA analysis; individuals' level of participation in expressions in the integrative needs and integrative function sub-dimensions do not differ according to their age $(\mathrm{p}=0,481$ and $\mathrm{p}=0,491>\alpha=$ 0.05). Participants' levels of participation in expressions in the sub-dimensions of cognitive needs, affective needs and needs related to escape differ according to the ages of the individuals $(p=0,007 ; p=0,036$ and $p=0,017<\alpha$ $=0,05)$. Also, Influencers satisfy the cognitive needs of individuals in the 18-19 age group more than individuals in other age groups. Influencers satisfy the affective needs of individuals in the 18-19 age group more than those in other age groups. Influencers satisfy the needs related to escape of individuals in the 23-25 age group more than individuals in other age groups.

In order to determine which age groups have the differences, Tukey analysis in the Post Hoc test group was used. According to Tukey analysis results; It was determined that the participation levels of the individuals in the 18-19 and 20-22 age groups regarding the expressions in the sub-dimensions of the cognitive and affective needs category differ in a statistically significant way (in order, $p=0,005$ and $p=0,045<\alpha=0,05$ ). Also, it was found that the participation levels of the individuals in the 20-22 and 23-25 age groups regarding the expressions in the subdimensions of needs related to escape differ statistically and significantly.

\subsubsection{ANOVA Analysis for the Educational Status of Individuals}

The results of the ANOVA analysis applied to determine whether the relationship between the educational status of the participants and their level of participation in the expressions in the scale differ or not is given in Table 12.

Table 12. Results of ANOVA Analysis on the Relationship Between Educational Status and Levels of Participation in Expressions in the Scale

\begin{tabular}{ccccccc}
\hline & Educational Status & N & Mean & SD & F & p \\
\hline \multirow{4}{*}{ CN } & Secondary Education & 159 & 4,1373 & 0,54137 & & \\
& Bachelor's Degree & 289 & 3,6430 & 0,76497 & & \\
& Postgraduate Degree & 65 & 3,7564 & 0,53528 & 27,645 & 000 \\
\hline \multirow{3}{*}{ AN } & Total & 513 & 3,8106 & 0,71049 & & 0,000 \\
& Secondary Education & 159 & 3,5870 & 0,41204 & & \\
& Bachelor's Degree & 289 & 3,2451 & 0,60985 & & \\
& Postgraduate Degree & 65 & 3,3692 & 0,30970 & 21,829 & \\
IN & Total & 513 & 3,3668 & 0,54498 & & 0,000 \\
& Secondary Education & 159 & 3,2914 & 0,38428 & & \\
\end{tabular}


Süleyman Demirel Üniversitesi Vizyoner Dergisi, Yıl: 2021, Cilt: 12, Sayı: 31, 955-971.

Süleyman Demirel University Visionary Journal, Year: 2021, Volume: 12, No: 31, 955-971.

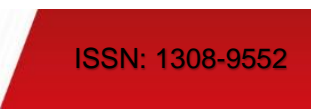

\begin{tabular}{ccccccc}
\hline & Educational Status & N & Mean & SD & F & p \\
\hline \multirow{4}{*}{ IF } & Secondary Education & 159 & 3,1918 & 0,47593 & & \\
& Bachelor's Degree & 289 & 2,9735 & 0,71650 & & \\
& Postgraduate Degree & 65 & 2,9154 & 0,40625 & 7,791 & 0,000 \\
\hline \multirow{3}{*}{ NRE } & Total & 513 & 3,0338 & 0,62521 & & \\
& Secondary Education & 159 & 3,9224 & 0,40382 & & \\
& Bachelor's Degree & 289 & 3,6684 & 0,69005 & & 0,000 \\
\hline
\end{tabular}

According to the results of ANOVA analysis; it was determined that the views on all expressions in the subdimensions of the Influencer Satisfaction Scale differ according to the education levels of the participants $(\mathrm{p}=$ $0,000<\alpha=0,05)$.

In order to determine which educational status have the differences, Tukey analysis in the Post Hoc test group was used. According to Tukey analysis results; influencers satisfy more cognitive needs, affective needs, integrative needs, integrative function and need related to escape of individuals', who have secondary education status, than individuals who have bachelor's or postgraduate degree status (in order, $p=0,000, p=0,000, p=0,000, p=0,001$ and $\mathrm{p}=0,000<\alpha=0,05)$. Also, influencers satisfy more needs related to escape of individuals', who have postgraduate degree status, than individuals who have bachelor's degree status $(\mathrm{p}=0,047<\alpha=0,05)$.

According to the information obtained as a result of the ANOVA analysis and Tukey analysis, it was determined that as the education level of the individuals increased, their level of participation in the statements in the scale decreased.

\subsubsection{ANOVA Analysis of Individuals' Internet Usage Frequency}

The details of the ANOVA analysis results applied to determine whether the participants' daily usage frequency of the internet and their level of participation regarding the expressions in the sub-dimensions of the scale differ or not are given in Table 13.

Table 13. Results of ANOVA Analysis on the Relationship Between Internet Usage Frequency and Levels of Participation in Expressions in the Scale

\begin{tabular}{|c|c|c|c|c|c|c|}
\hline & Frequency & $\mathbf{N}$ & Mean & SD & $\mathbf{F}$ & p \\
\hline \multirow{5}{*}{$\mathrm{CN}$} & 1-3 hours & 43 & 3,2519 & 0,89411 & \multirow{5}{*}{27,822} & \multirow{5}{*}{0,000} \\
\hline & 3-5 hours & 113 & 3,5265 & 0,63838 & & \\
\hline & 5-7 hours & 174 & 3,8458 & 0,65501 & & \\
\hline & $10+$ hours & 183 & 4,0838 & 0,61396 & & \\
\hline & Total & 513 & 3,8106 & 0,71049 & & \\
\hline \multirow{5}{*}{$\mathrm{AF}$} & $1-3$ hours & 43 & 3,0349 & 0,66125 & \multirow{5}{*}{19,391} & \multirow{5}{*}{0,000} \\
\hline & 3-5 hours & 113 & 3,1726 & 0,60213 & & \\
\hline & 5-7 hours & 174 & 3,3755 & 0,49449 & & \\
\hline & $10+$ hours & 183 & 3,5565 & 0,43974 & & \\
\hline & Total & 513 & 3,3668 & 0,54498 & & \\
\hline \multirow{5}{*}{ IN } & $1-3$ hours & 43 & 2,8953 & 0,62469 & \multirow{5}{*}{10,177} & \multirow{5}{*}{0,000} \\
\hline & 3-5 hours & 113 & 2,9853 & 0,53106 & & \\
\hline & 5-7 hours & 174 & 3,1351 & 0,52165 & & \\
\hline & $10+$ hours & 183 & 3,2714 & 0,49705 & & \\
\hline & Total & 513 & 3,1306 & 0,53840 & & \\
\hline
\end{tabular}


Süleyman Demirel Üniversitesi Vizyoner Dergisi, Yıl: 2021, Cilt: 12, Sayı: 31, 955-971. Süleyman Demirel University Visionary Journal, Year: 2021, Volume: 12, No: 31, 955-971.

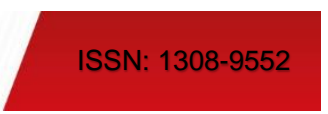

\begin{tabular}{|c|c|c|c|c|c|c|}
\hline & Frequency & $\mathbf{N}$ & Mean & SD & $\mathbf{F}$ & $\mathbf{p}$ \\
\hline \multirow{5}{*}{ IF } & $1-3$ hours & 43 & 2,6860 & 0,71567 & \multirow{5}{*}{18,662} & \multirow{5}{*}{0,000} \\
\hline & 3-5 hours & 113 & 2,8127 & 0,60755 & & \\
\hline & 5-7 hours & 174 & 3,0287 & 0,58739 & & \\
\hline & $10+$ hours & 183 & 3,2568 & 0,56336 & & \\
\hline & Total & 513 & 3,0338 & 0,62521 & & \\
\hline \multirow{5}{*}{ NRE } & $1-3$ hours & 43 & 3,4612 & 0,83874 & \multirow{5}{*}{13,052} & \multirow{5}{*}{0,000} \\
\hline & $3-5$ hours & 113 & 3,5752 & 0,66741 & & \\
\hline & 5-7 hours & 174 & 3,8266 & 0,49023 & & \\
\hline & $10+$ hours & 183 & 3,9117 & 0,48600 & & \\
\hline & Total & 513 & 3,7710 & 0,58733 & & \\
\hline
\end{tabular}

According to the results of ANOVA analysis; it was determined that the daily internet usage frequency of the individuals and their level of participation for all the expressions differ in the sub-dimensions of the scale. It was found that the participation level of individuals in expressions contained on the scale increases in direct proportion to the frequency of daily internet use. It was determined that all of the individuals who gave the most positive opinion to all statements in the sub-dimensions of the scale and had the highest level of participation were those who used the internet for 10 hours or more per day (mean of all sub-dimensions in order, 4,0838; 3,5565; 3,2714; 3,2568 and 3,9117).

\section{CONCLUSION}

Developments in internet and communication technologies increase the power and appeal of social media day by day. The instant communication and interaction feature offered by online social platforms to their users makes it indispensable for individuals. Social media not only isolates communication and interaction from time and space, but also opens the door to the digital universe by offering its users the opportunity to create a virtual identity. Users can assume the identity they want in this infinite universe, spend as much time as they want in virtual space under the invisibility cloak, and share information, photos and videos with their friends. It is not always easy to adapt to the speed of social media applications, which add a different feature every day. This process may take some time, especially for individuals of Generation $\mathrm{X}$ and $\mathrm{Y}$. However, it is an undeniable fact that individuals of Generation $\mathrm{Z}$ can minimize this adaptation process and have the ability to adapt to innovations in a very short time. Because the individuals of this generation open their eyes to technology and have been growing and developing intertwined with technology from the moment they were born. Therefore, it is observed that individuals of Generation $\mathrm{Z}$ use social media to satisfy their different needs compared to individuals in other generation groups.

The data collected within the scope of the research were first analyzed in order to determine the demographic characteristics of the participants. In the next step, descriptive analysis was carried out in order to determine which of the expressions included in the scale participated more. Afterwards, the data were subjected to Independent Sample T-Test and ANOVA analysis in order to determine whether individuals' level of participation in expressions differ according to gender, age, education level and frequency of internet use, and Tukey analysis was used to find the source of the differences. The following important points come to the fore within the framework of the analyzes made and the results reached:

Generation Z individuals rely heavily on influencers' feelings, thoughts and experiences about the product or service before they adopt a purchasing attitude towards a product or service, and they are affected by their discourse. Considering this situation, it is observed that the individuals of Generation $\mathrm{Z}$ exhibit a different attitude from traditional methods in shopping, conduct research on the internet for the product or service they will purchase, and benefit from the experiences and discourses of those they trust. Therefore, if it is necessary to make a suggestion based on this result, brands and organizations should put aside traditional attitudes in product and service marketing for Generation $\mathrm{Z}$ individuals, and should be aware of the fact that they should benefit from the blessings of digital effectively in order to attract the attention of children of the digital age.

It was found that another important reason for the relationship between Generation $\mathrm{Z}$ individuals and Influencers is the element of excitement. In order to satisfy their adrenaline needs and to get rid of the monotony of life, 
individuals turn to the profiles/channels of people with high excitement levels. Another important expression with the highest average level of participation on the scale is the expression of the desire of Generation $\mathrm{Z}$ individuals to succeed. At this point, it is possible to say that influencers, who are successful in the field of individuals, aim to raise their success levels even higher by choosing a role model for themselves. Another expression accepted by Generation $\mathrm{Z}$ individuals is that influencers help themselves to the acquisition of a new social environment. Influencers can be people whose fan base is expressed in millions. Therefore, dozens of fan pages can be created by the mass of followers on behalf of these individuals. Through this initiative, individuals can create new communities for an influencer they love, and have the opportunity to interact and meet new people with the same purpose.

Finally, the expression on the scale, which has the highest average level of participation by Generation $\mathrm{Z}$ individuals, is that the internet helps individuals live in their own imagination, free from the troubles of social life. Financial and moral problems can be the source of many difficulties in the social lives of individuals. People may be helpless in some situations and feel incapable of dealing with problems. At this point, the infinite virtual universe offered by the internet acts as a savior for individuals. Individuals can get away from the difficulties and troubles of social life, even temporarily, through the internet, and have the opportunity to be alone with their dreams in the infinity of digital by assuming the virtual identity they want.

Undoubtedly, the internet and online social platforms are considered as the greatest blessings of our age, but they can cause destructive consequences when used outside of their intended purpose. For members of Generation $\mathrm{X}$ and $\mathrm{Y}$ who have met the Internet relatively late, online social platforms or, as it is commonly called, virtual space may not make much sense, but this is one of the indispensable elements of Generation Z. The needs and expectations of the children of the digital age are developing and differentiating simultaneously with technology. Influencers, who increase the number of followers every second and add strength to their interaction power, seem to be talking about themselves more in the future. Therefore, the interaction and satisfaction relationship between these two groups will always be an important study subject that awaits research and consideration.

\section{DECLARATION OF THE AUTHORS}

Declaration of Contribution Rate: The first author contributes 70\% while the second author contributes $30 \%$.

Declaration of Support and Thanksgiving: No support is taken from any institution or organization.

Declaration of Conflict: There is no potential conflict of interest in the study.

\section{REFERENCES}

Aslan, A. ve Ünlü, G. Ü. (2016). Instagram fenomenleri ve reklam ilişkisi: Instagram fenomenleri gözünden bir değerlendirme. Maltepe Üniversitesi İletişim Fakültesi Dergisi, 3(2), 41-65.

Ayhan, B. ve Çavuş, S. (2014). İzleyici araştırmalarında değişim: Kullanımlar ve doyumlardan bağımlılığa. Selçuk İletişim, 8(2), 32-60.

Bal, E. (2013). Teknoloji çağında cep telefonu kullanım alışkanlıkları ve motivasyonlar: Selçuk Üniversitesi ögrencileri üzerine bir inceleme. Doktora Tezi, Selçuk Üniversitesi Sosyal Bilimler Enstitüsü, Konya.

Baysal Berkup, S. (2014). Working with generations X and Y in generation Z period: Management of different generations in business life. Mediterranean Journal of Social Sciences, 5(19), 218-229.

Birsen, Ö. (2005). Çok seçenekli medya ortamında kitle iletişim araçlarının tüketim ve seçim biçimi: Eskişehir örnekleminde bir izler kitle araştırması. Doktora Tezi, Anadolu Üniversitesi Sosyal Bilimler Enstitüsü, Eskişehir.

Blumler, J. G. (1979). The role of theory in uses and gratifications studies. Communication Research, 6(1), 9-36.

Boyd, D. M. and Ellison, N. B. (2008). Social network sites: Definition, history, and scholarship. Journal of Computer-Mediated Communication, 13(1), 210-230.

Bozarth, J. (2010). Social media for trainers. San Francisco: Pfeiffer Publish. 
Süleyman Demirel Üniversitesi Vizyoner Dergisi, Yıl: 2021, Cilt: 12, Sayı: 31, 955-971.

Süleyman Demirel University Visionary Journal, Year: 2021, Volume: 12, No: 31, 955-971.

Brown, D. and Hayes, N. (2008). Influencer marketing: Who really influences your customers?. New York: Routledge.

Büyüköztürk, Ş. (2006). Veri analizi el kitabı. Ankara: Pegem Akademi Yayınc1lık.

Chen, G. M. (2011). Tweet this: A uses and gratifications perspective on how active twitter use gratifies a need to connect with others. Computers in Human Behavior, 27(2), 755-762.

Csobanka, Z. E. (2016). The Z generation. Acta Technologica Dubnicae, 6(2), 63-76.

Çakın, Ö. (2018). Bir ürün yerleştirme mecrası olarak Instagram ve Instagram fenomenleri. N. Bolat (Ed.), Ürün yerleştirme uygulamaları içinde (195-213), Konya: Literatürk Academia.

Çakır, V. (2005). Bir sosyal etkinlik olarak eğlence ve televizyon: Konya örneği. Doktora Tezi, Selçuk Üniversitesi Sosyal Bilimler Enstitüsü, Konya.

Çakır, V. ve Çakır, V. (2010). Televizyon bağımlılığı. Konya: Literatürk Academia.

Erdem, M. N. (2018). Markalar oyunda! dijitalde bir ürün/marka yerleştirme alanı olarak gama-Vertising. N. Bolat (Ed.), Ürün Yerleştirme Uygulamaları içinde (215-265). Konya: Literatürk Academia.

Erdoğan, İ. ve Alemdar, K. (1990). İletişim ve toplum. Ankara: Bilgi Yayınevi.

Fiske, J. (2003). İletişim çalışmalarına girişs. S. İrvan (Çev.), Ankara: Bilim ve Sanat.

Hatton, G. (2018). Micro Influencers vs macro influencers. Erişim adresi: https://www.socialmediatoday.com/news/micro-influencers-vs-macro-influencers/516896/, (23.04.2021).

Hazar, M. (2011). Sosyal medya bağımlılı̆̆ - Bir alan çalışması. İletişim Kuram ve Araştırma Dergisi, 32, 151176.

Kangur, K. (2021). How to boost ecommerce sales with influencer marketing. Erişim adresi: https://www.socialbakers.com/blog/6-ways-to-boost-e-commerce-sales-with-influencer-marketing, (24.04.2021).

Kaplan, A. and Haenlein, M. (2010). Users of the world, unite! The challenges and opportunities of social media. Business Horizons, 53(1), 59-68.

Karadoğan, A. (2019). Z kuşağı ve öğretmenlik mesleği. Ağr İbrahim Çeçen Üniversitesi Sosyal Bilimler Enstitüsü Dergisi, 5(2), 9-41.

Katz, E., Blumler, J. G. and Gurevitch, M. (1973-1974). Uses and gratifications research. Public Opinion Quarterly, 37(4), 509-523.

Katz, E., Gurevitch, M. and Haas, H. (1973). On the use of mass media for important things. American Sociological Review, 38(2), 164-181.

Kırık, A. M. and Köyüstü, S. (2018). Z Kuşağı konusunda yapılmış tezlerin içerik analizi yöntemi ile incelenmesi. E-Gifder, 6(2), 1497-1517.

Kim, J-Y. (2002). A cross-media study of koreans' media choice process and consumption patterns in the new media environment. $\mathrm{PhD}$. Thesis, The University of Southern Mississippi Advisor Department of Mass Communication and Journalism, Hatissburg.

Kim, W., Jeong, O-R. and Lee, S-W. (2010). On social web sites. Information Systems, 35(2), 215-236.

Kotler, P. and Armstrong, G. (2011). Principles of marketing. New Jersey: Pearson Prentice Hall.

Köseoğlu, Ö. (2012). Sosyal ağ sitesi kullanıcılarının motivasyonu: Facebook üzerine bir araştırma. Selçuk İletişim, 7(2), 58-81.

Kuyucu, M. (2016). Kullanımlar ve doyumlar perspektifinden radyo dinleme alışkanlıkları ve doyumları. Proceedings of SOCIOINT 2016 3rd International Conference on Education, Social Sciences and Humanities. 23-25 Mayıs 2016, İstanbul. 
Laughey, D. (2010). Medya çalışmaları: Teoriler ve yaklaşımlar. A. Toprak (Trans.), İstanbul: Kalkedon Yayınlar1.

Littlejohn, S. W. and Foss, K. A. (2009). Encyclopedia of Communication Theory. Thousand Oaks: SAGE.

Lull, J. (2001). Medya İletişim Kültür. N. Güngör (Çev.), Ankara: Vadi Yayınevi.

Newson, A., Houghton, D. and Patten, J. (2008). Blogging and other social media: Exploiting the technology and protecting the Enterprise. USA: Gower Publishing Limited.

Özdamar, K. (2002). Paket programlar ile istatistiksel veri analizi. Eskişehir: Kaan Kitabevi.

Rubin, A. M. (2002). The uses and gratifications perspective of media effects. J. Bryant (Ed.), Media Effects: Advances in Theory and Research içinde (525-548). USA: Lawrence Erlbaum Associates.

Severin, W. J. and Tankard, J. W. (1994). Iletişim kuramları. A. A. Bir ve S. Sever (Trans.), Eskişehir: Kibele Sanat Merkezi.

Sladek, S. and Grabinger, A. (2013). Gen Z: The first generation of 21st century has arrived!. Erişim adres: https://www.xyzuniversity.com/wp-content/uploads/2018/08/GenZ_Final-dl1.pdf, (25.04.2021).

Sucu, İ. (2014). Kullanımlar ve doyumlar yaklaşımı açısından sosyal medya sanal dünya oyunu olarak second life örneği. Doktora Tezi, Maltepe Üniversitesi Sosyal Bilimler Enstitüsü, İstanbul.

Turow, J. (2009). Media today: An introduciton to mass communication. New York: Routledge.

Tuten, T. L. and Solomon, M. R. (2018). Social media marketing. United Kingdom: SAGE Publications Ltd.

Uzun, R. (2013). İzleyici Merkezli Yaklaşımlar. E. Yüksel (Ed.), İletişim Kuramları içinde (84-105). Eskişehir: Anadolu Üniversitesi Açıköğretim Fakültesi Yayınları.

Zietek, N. (2016). Influencer marketing: The characteristics and components of fashion influencer marketing. Master Thesis, University of Borås Faculty of Textiles, Engineering and Business, Sweden. 